\title{
Workload associated with mrsa control in surgery: a prospective study alongside a controlled clinical trial
}

\author{
S Bahrami ${ }^{1 *}$, AS Lee ${ }^{2}$, S Harbarth ${ }^{3}$, S Malhotra-Kumar ${ }^{4}$, C Brun-Buisson ${ }^{5}$, I Durand-Zaleski ${ }^{1}$, \\ MOSAR WP9 and WP4 working groups \\ From 3rd International Conference on Prevention and Infection Control (ICPIC 2015) \\ Geneva, Switzerland. 16-19 June 2015
}

\section{Introduction}

Controversies regarding control of endemic methicillinresistant Staphylococcus aureus (MRSA) stem in part from the paucity of data available on the actual costs of implementing MRSA control strategies.

\section{Objectives}

To estimate the workloads associated with screening and hand hygiene $(\mathrm{HH})$ promotion interventions for MRSA control.

\section{Methods}

Prospective evaluation of costs associated with MRSA control interventions, alongside the MOSAR-Surgery multicenter intervention trial [1], emphasizing the workloads associated with interventions. Interventions under study were (1) universal MRSA screening with contact precautions and decolonization (4 hospitals) and (2) enhanced $\mathrm{HH}$ promotion (4 hospitals); 2 hospitals implemented a combined strategy using targeted MRSA screening.

Workloads were estimated from a hospital perspective, using a top-down approach, distinguishing infection control (IC) and ward staff duties, set-up and routine activities, and excluding research-driven tasks.

\section{Results}

In the screening arm (13 wards; mean, $27.8 \pm 10.4$ beds), set-up required $2.6 \pm 0.58$ weeks of work from the IC team, and the mean annual workload was 20.5 weeks or $8.62 \pm 4.39$ weeks for a 10 -bed ward. In the $\mathrm{HH}$ promotion arm (13 wards, $87.8 \pm 79.5$ beds), set-up required $2.77 \pm 1.13$ weeks, and mean annual workload was 12.1 weeks ( $3.29 \pm 3.72$ per 10 beds). In the combined arm (7 wards, $44.9 \pm 24.6$ beds), set-up required $7.0 \pm 1.93$ weeks, and mean annual workload was 23.7 weeks (5.94 \pm 1.84 weeks per 10 beds). The burden on ward staff was relatively limited in most wards.

\section{Conclusion}

Workload associated with the MRSA screening strategy is relatively homogenous and predictable. Investment in the $\mathrm{HH}$ promotion strategy showed large variations between centers and was maximal for the successful combined intervention. Further research is needed on the optimal implementation of $\mathrm{HH}$ promotion interventions.

\section{Disclosure of interest}

S. Bahrami: None declared, A. Lee: None declared, S. Harbarth Grant/Research support from: Geneva University Hospitals, B. Braun, Pfizer, Speaker's bureau of: BioMerieux, Pfizer, Conflict with: Scientific Advisory Board, Destiny Pharma, DaVolterra, BioMérieux, S. Malhotra-Kumar: None declared, C. Brun-Buisson: None declared, I. Durand-Zaleski: None declared.

\footnotetext{
Authors' details

${ }^{1}$ AP-HP, Paris, France. ${ }^{2}$ Royal Prince Alfred Hospital, Sydney, Australia.

${ }^{3}$ University of Geneva Hospitals, Switzerland. ${ }^{4}$ University of Antwerp, Belgium. ${ }^{5}$ Inserm U657, Paris, France.
}

Published: 16 June 2015 


\section{Reference}

1. Lee AS, Cooper BS, Malhotra-Kumar S, et al: BMJ Open 2013, 3:e003126.

doi:10.1186/2047-2994-4-S1-P188

Cite this article as: Bahrami et al.: Workload associated with mrsa

control in surgery: a prospective study alongside a controlled clinical trial. Antimicrobial Resistance and Infection Control 2015 4(Suppl 1):P188.

Submit your next manuscript to BioMed Central and take full advantage of:

- Convenient online submission

- Thorough peer review

- No space constraints or color figure charges

- Immediate publication on acceptance

- Inclusion in PubMed, CAS, Scopus and Google Scholar

- Research which is freely available for redistribution 